БУТЕНКО В. М., канд. техн. наук, доцент ${ }^{1}$,

ГОЛОВКО О. В., канд. техн. наук, доцент, ${ }^{1}$

СЕРГІСНКО Р. П., канд. техн. наук, ${ }^{2}$

ЧУБ С. Г., канд. техн. наук, доцент ${ }^{2}$,

( ${ }^{1}$ Український державний університет залізничного транспорту)

( ${ }^{2}$ ДП «Харківстандартметрологія»)

\title{
Удосконалення принципових схем інформаційно-вимірювальних та комутаційних компонентів систем залізничної автоматики електронними засобами комп'ютерної інженерії
}

Наведено результати досліджень схемотехнічних рішень електронних реле, які застосовуються у складі пристроїв і систем залізничної автоматики та телемеханіки залізничної автоматики. Подібні розробки для прикладних задач досі не набули значного поширення. Розроблено методи та схемні рішення електронних вузлів - аналогів котушки та контактів реле. Ці розробки є перспективними для створення нових електронних реле як компонентів для автоматики систем управління залізничного транспорту.

Ключові слова: електронне реле, контакт, комутатор, оптрон, MOSFET-транзистор.

Вступ

Технічне переоснащення вітчизняної залізниці, зокрема впровадження нових розподілених засобів та систем залізничної автоматики $[1$, с. 15], на сьогоднішній день є одним 3 важливих напрямів розвитку систем управління залізничною галуззю. Серед вирішуваних проблем $\epsilon$ задачі оптимізації розподілених структур таких засобів [2, с. 12].

\section{Постановка проблеми}

Існуючі системи вітчизняної залізничної автоматики побудовані з використанням різноманітних електромеханічних реле (далі - ЕМР) [3, с. 3]. Ці реле були розроблені достатньо давно, за радянських часів, і сьогодні практично не виробляються в Україні. Але до випробувань обчислювальних компонентів та систем, побудованих на сучасних електронних елементах, державою висунуто низку вимог [4; 5, с. 3], що на сьогодні потребують перегляду через недоліки у практичному застосуванні випробувань [6, с. 31].

\footnotetext{
Аналіз останніх досліджень і публікацій

Розглянемо нейтральні реле клапанного типу. Для них силу притягання якоря до полюса осердя можна оцінити за співвідношенням, що виводиться з формули Максвелла [7, с. 87; 8, с. 3]:
}

$$
F=6,4 \cdot 10^{-8} \frac{I^{\vartheta^{2}} w^{2} S}{\delta^{2}}[k z],
$$

де $I^{\ni}$ - максимальна сила струму в обмотці; $\delta$ повітряний проміжок між якорем і полюсом; $w$ кількість витків в обмотці; $S$ - площа торця осердя.

Розглянемо коливання пластини при відпущеному контакті на прикладі консольної балки, закріпленої 3 одного боку (рис. 1) [9, с.12].

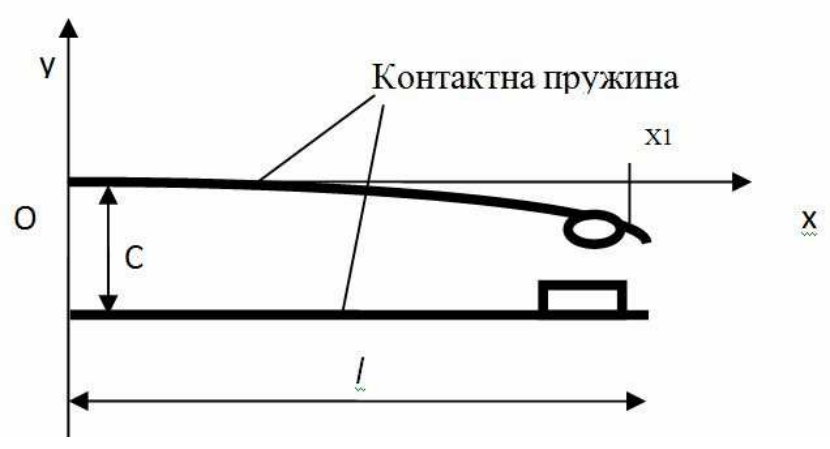

Рис. 1. Схема задачі

(근. М. Бутенко, О. В. Головко, Р. П. Сергієнко, С. Г. Чуб, 2021 
Для контактних пластин реле після виведення його зі стану рівноваги можуть виникнути стоячі хвилі, кожна 3 яких являє собою одне власне коливання 3 певною частотою. Позначимо функцію величини коливання пластини в точці $x$ у момент часу $t$ як $Y(x, t)$. Рівняння поперечних коливань для однорідного стержня, товщиною якого можна буде знехтувати, має такий вигляд:

$$
\frac{d^{2} Y}{d t^{2}}+\frac{E J}{m} \frac{d^{4} Y}{d x^{4}}=0
$$

де $E$ - модуль Юнга матеріалу балки;

$J$ - момент інерції пластини;

$m$ - маса балки (пластини).

Для контактних пластин довжиною застосовуються такі граничні умови:

$Y(0, t)=d Y(0, t) / d x=d^{2} Y(l, t) / d x^{2}=d^{3} Y(l, t) / d x^{3}=0$.

Якщо розглядати верхню контактну пластину як стержень (балку), в якій проходять коливання при дії на неї поперечної сили, що позначається формулою

$F(x, t)=f(x) e^{i \omega t}$,

то стержень буде здійснювати змушені коливання, рівняння яких має вигляд:

$\frac{d^{2} Y}{d t^{2}}+\frac{E J}{m} \frac{d^{4} Y}{d x^{4}}=F(x, t)$

Для цього рівняння існує рішення, яке отримується за допомогою перетворення Лапласа [10, с.1]:

$$
\begin{aligned}
& Y_{o}(x)=\frac{F}{E J D\left(b_{o} l\right) b_{o}{ }^{3}}\left(\left(S\left(b_{o} l\right) T\left(b_{o}\left(l-x_{1}\right)\right)-\right.\right. \\
& \left.-T\left(b_{o} l\right) S\left(b_{o}\left(l-x_{1}\right)\right)\right) U\left(b_{o} x_{1}\right)+\left(S\left(b_{o} l\right) S\left(b_{o}\left(l-x_{1}\right)\right)-\right. \\
& \left.\left.-V\left(b_{o} l\right) T\left(b_{o}\left(l-x_{1}\right)\right)\right) V\left(b_{o} x\right)\right)+ \\
& +\frac{F}{E J D\left(b_{o} l\right) b_{o}{ }^{3}} V\left(b_{o}\left(x-x_{1}\right)\right)
\end{aligned}
$$

де

$$
\begin{aligned}
& T\left(b_{0} x\right)=1 / 2\left(\operatorname{sh}\left(b_{0} x\right)+\sin \left(b_{0} x\right)\right), \\
& S\left(b_{0} x\right)=1 / 2\left(\operatorname{ch}\left(b_{0} x\right)+\cos \left(b_{0} x\right)\right), \\
& U\left(b_{0} x\right)=1 / 2\left(\operatorname{ch}\left(b_{0} x\right)-\cos \left(b_{0} x\right)\right), \\
& V\left(b_{0} x\right)=1 / 2\left(\operatorname{sh}\left(b_{0} x\right)-\sin \left(b_{0} x\right)\right), \\
& D\left(b_{0} l\right)=T\left(b_{0} l\right) V\left(b_{0} l\right)-S^{2}\left(b_{0} l\right), \\
& b_{0}=\left(\sqrt[4]{\frac{m}{E J}}\right) \sqrt{\omega}
\end{aligned}
$$

$\omega$ - частота коливань;

$m$ - маса балки.

\section{Виділення не вирішених раніше частин загальної проблеми}

Зазначені коливання пластини вносять суттєві недоліки у функціонування електромагнітних реле. Подальший розвиток комутаційних елементів здійснювався по шляху застосування електронних ключів для зменшення впливу зазначених вище коливань пластини й підвищення експлуатаційної надійності підсистем залізничної автоматики в цілому. Таким чином, маємо можливість сформулювати мету i завдання дослідження.

\section{$l$ Формулювання мети і завдання дослідження}

Метою роботи $\epsilon$ розробка та обгрунтування схемотехнічних рішень важливих складових частин $\mathrm{EP}$, які б у подальшому могли стати типовими для застосування в складі вузлів, підсистем та систем залізничної автоматики як компонентів спеціалізованих комп'ютерних систем технологічних обчислень безпечності маршрутів прямування.

Останнім часом серед засобів залізничної автоматики набули певного поширення електронні реле (далі - ЕР), які відтворюють функції аналогічних за призначенням електромагнітних реле залізничної автоматики. Розробники ЕР здебільшого не мають на меті широкого оприлюднення особливостей своїх розробок з міркувань збереження власних комерційних таємниць. Через це їхні кінцеві продукти - EР суттєво відрізняються одне від одного за своєю будовою, ремонтопридатністю та іншими важливими характеристиками. Водночас провідні світові розробники електронних (твердотілих) реле загального призначення (приклад - OMRON) мають певний досвід і типові промислові рішення, які позитивно зарекомендували себе у різних галузях. Однак слід зазначити суттєву різницю між реле загального призначення та ЕР для потреб залізничної автоматики. Так, останні відрізняються високими вимогами до рівня надійності та функціональної безпечності. Таким чином, достатньо актуальною $\epsilon$ розробка схемотехнічних рішень ЕР, які $б$ охоплювали позитивний досвід вітчизняних розробників і містили передові рішення світових лідерів.

\section{Виклад основного матеріалу дослідження}

Слід зазначити, що ЕР мають певні переваги над ЕМР-аналогами. Насамперед це висока надійність контактування. Нормою для ЕMP першого (найкращого) класу надійності $€$ один мільйон гарантованих спрацювань без електричного навантаження на контакти. Звичайні електронні контакти таку норму легко перекривають на декілька 
порядків і не мають проблем, пов'язаних 3 іскроутворенням. Однак електронні контакти мають і свої особливості. Якщо для механічного контакту немає різниці, які сигнали (змінного або постійного струму) комутувати, то комутація різноманітних сигналів за допомогою ЕР потребує різних електронних комутуючих приладів. Слід також зазначити певну особливість фронтових (нормальнорозімкнених) контактів ЕМР - вони виконуються 3 вугільно-срібляних сумішей i не мають ефекту приварювання один до одного. Це обов'язкова вимога до фронтових контактів ЕМР, яка повною мірою поширюється і на комутуючі пристрої ЕР. Через це не всі комутуючі прилади $\epsilon$ придатними для використання у схемах ЕР. До таких належать, зокрема, симістори, для яких типова відмова полягає у постійному короткому замиканні, що $\epsilon$ неприпустимим.

На сьогоднішній день найбільш широко в схемах EP як електронні контакти застосовують MOSFETтранзистори 3 індукованим каналом [11, с.1], що проводить струм без зазначених недоліків. Відмінність цього приладу: при виході його 3 ладу (відмові) провідність каналу зникає. Тобто ця відмова за наслідками $\epsilon$ аналогічною до відмови фронтового контакту ЕМР, а саме обриву.

Типову схему електронного комутатора сигналів змінного струму (або сигналів постійного струму довільної полярності) наведено на рис. 2. Вона містить два MOSFET-транзистори - VT1 і VT2, затвори та витоки яких попарно з'єднані між собою, а витоки є входами-виходами комутатора.

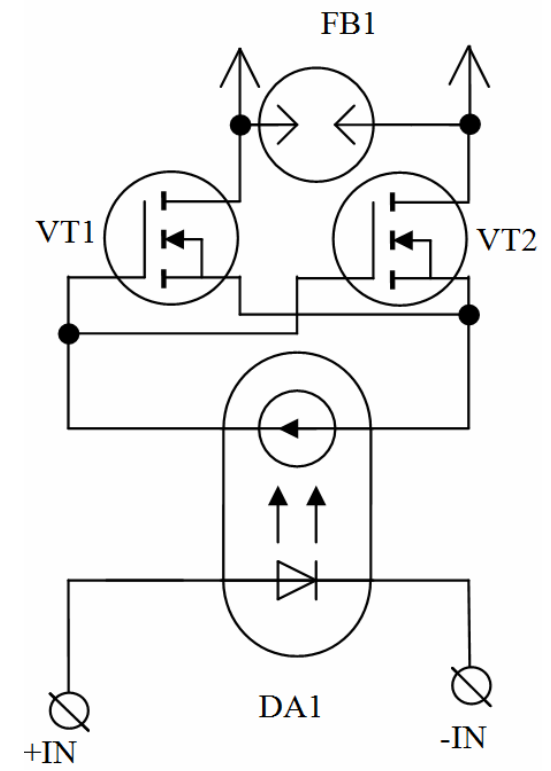

Рис. 2. Електронний комутатор сигналів змінного струму
Кожен MOSFET-транзистор має вбудовану в його кристал структуру, яка виконує функції захисного діода (на рисунку не показано), увімкнутого паралельно у протилежний до каналу сток-виток полярності VT1 і VT2 та спроможного пропускати струм, аналогічний до струму через сток-виток транзистора. Завдяки цим діодам разом 3 відкритими каналами транзисторів утворюється таке коло проходження комутованого сигналу довільної полярності: сток-виток одного транзистора - захисний діод іншого транзистора - виток іншого транзистора.

Умовою утворення каналу, що проводить струм, $є$ подавання на затвор транзистора напруги певного рівня (здебільшого 5-10 $\mathrm{B})$. Затвори MOSFETтранзисторів $€$ ізольованими, тому споживання струму цим ланцюгом від керуючої напруги у статичному режимі практично відсутнє. Це надає змогу керувати комутуючою схемою за допомогою надзвичайно малопотужного джерела напруги. Для керування MOSFET розроблені та широко застосовуються спеціальні фотовольтаїчні оптрони. Такий оптрон має на вході традиційний світлодіод, а на виході фотогальванічну схему - DA1 (рис. 2), яка під дією випромінювання вхідного світлодіода виробляє напругу керування 5-6 В, достатню для надійного відкривання транзисторів [11, с.1]. Струм, який можна отримати від цієї напруги, складає одиниці мікроампер, однак цього достатньо для керування MOSFET. Рівень розв'язки вхідного кола типового фотовольтаїчного оптрона від його виходу цілком задовольняе вимоги до засобів автоматики залізничного призначення $[3, \quad$ с. 3$]$. За умов пропускання номінального струму спрацювання через вхідне коло DA1: «+IN - світлодіод DA1 - -IN» оптрон спрацює, необхідна керуюча напруга на його виході утвориться і VT1 та VT2 відкриються.

Слід зауважити, що вимоги до залишкового електричного опору контактів EMP (та ЕР), що спрацювали, є досить жорсткими і складають частки Ом. Сучасні MOSFET-транзистори мають опір відкритого каналу за максимально-допустимої напруги між витоком і стоком закритого каналу 500 - 600 В і спроможні пропускати струм у десятки ампер [11, с.1]. Такі параметри $є$ цілком достатніми для потреб виробів залізничної автоматики. Однак вихідні кола MOSFET-комутаторів потребують захисту від короткоплинних перенапруг, які можуть виникнути у колах навантаження, особливо навантаження із суттєвою реактивною складовою. Такі функції захисту можуть бути реалізовані за допомогою супресорів, варисторів та розрядників. Усі ці елементи $\epsilon$ пороговими, розрахованими на широкий спектр напруг спрацювання та потужностей і вмикаються паралельно виходу комутатора. Супресор $є$ найбільш швидкодійним елементом, спроможним прийняти на себе вплив імпульсних перенапруг певної потужності, 
починаючи від імпульсів наносекундного діапазону $[12$, с.1]. Але у застосуванні цих елементів у схемах EMP $\epsilon$ певна складність - дуже високі вимоги до опору розімкнутих контактів. Зокрема такий опір має складати не менше 100 МОм за нормальних кліматичних умов. Зазначена норма $\epsilon$ достатньо жорсткою не тільки для супресорів та варисторів $[13$, c.1], а й для MOSFET. Сдиним елементом захисту, який відповідає зазначеній нормі, є розрядник (FB1 на рис. 2), але його треба віднести до повільно діючих, тобто комутуючих транзисторів, та ще й на деякий час, поки не спрацює розрядник, він повинен приймати вплив перенапруги на себе - бути певною мірою стійким до впливу імпульсних перенапружень.

Типові ЕМР містять у своєму складі так звані трійники - сукупність нормально-розімкненого (фронтового) та нормально-замкненого (тилового) контактів. Відтворення електронного нормальнозамкненого контакту становить певну проблему. Існуючі MOSFET-транзистори 3 вбудованими затворами та каналами збідненого типу мають відкриті канали з провідністю за відсутності керуючої напруги, які закривають ці канали при появі керуючої напруги на затворі. Але на сьогоднішній день такі транзистори не набули значного поширення як самостійні комутуючі прилади і здебільшого використовуються в складі малопотужних твердотілих реле як вбудовані елементи [12, с. 1]. Розглянуті транзистори є суттєво малопотужними та значно дорожчими у порівнянні 3 MOSFET-транзисторами 3 індукованим каналом. Виходом 3 цього становища для створення електронного тилового контакту є використання пари MOSFET-транзисторів VT3, VT4, попередньо відкритих від постійно діючого джерела живлення Vживл (рис. 3). Резистор R2 забезпечує номінальний струм керування оптроном DA2. Завдяки такому підходу виникає можливість для створення електронних комутаторів використовувати ідентичні комутуючі прилади. Електронний трійник утворюється аналогічно до схем ЕMP послідовним з'єднанням виходів VT1 фронтового і VT3 тилового контактів (рис. 3).

Щодо джерела живлення - воно потрібне не тільки для живлення тилових контактів, але й для живлення схеми електронного аналога котушки ЕР. Це живлення теоретично можливо здійснити за рахунок напруги (струму) вхідного керуючого сигналу, який надходить до ЕР.

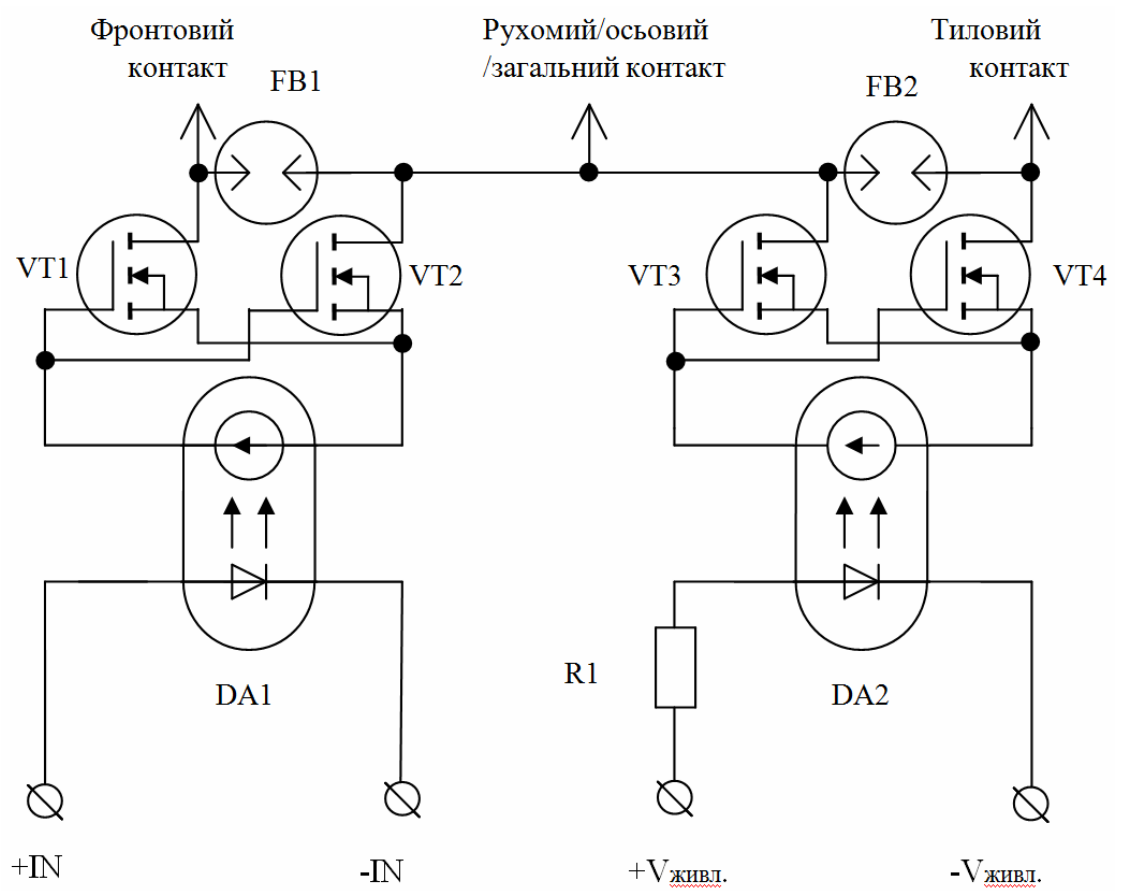

Рис. 3. Принципова схема електронного трійника

Таке рішення має певні недоліки, зокрема підвищує потужність, що споживається реле від кіл керуючого сигналу. Ця потужність нормується. Так, потужність, споживана ЕMР першого класу надійності від кіл керуючого сигналу, має не перевищувати 1 Вт.
Типове ЕР містить декілька (4-8) трійників. Для живлення кожного тилового контакту потрібно окреме ізольоване джерело напруги. А для живлення тилових контактів усіх трійників потрібно 4-8 джерел напруги, які достатньо ізольовані одне від одного. Найбільш простим способом реалізації цієї вимоги $\epsilon$ 
застосування групи з 4-8 вольтаїчних оптронів, вхідні світлодіоди яких під'єднані до живлення. Керування тиловими контактами буде полягати у знеживленні у той чи інший спосіб вхідних світлодіодів оптронів.

Особливості електронних аналогів котушок ЕР

Електронні аналоги котушок ЕР (далі - КЕР) можуть бути виконані за різноманітними схемами, залежно від особливостей вхідного керуючого сигналу (змінні або постійні напруга, струм, а також рівень, зміна полярності і т. ін.). Однак $є$ актуальним віднайти достатньо універсальні схемні рішення, за допомогою яких можна було б реалізувати аналоги котушок різноманітних ЕР ідентичними схемними рішеннями.

Основними загальними вимогами до КЕР є: ідентичність параметрів (електричний опір, споживаний струм, рівні спрацювання / відпускання і т. ін.) 3 їхніми прототипами котушок ЕMP, а також надійна гальванічна розв'язка від кіл силових контактів. Крім того, 3 міркувань здорового глузду, можна зауважити, що чим менше елементів КЕР $\epsilon$ гальванічно зв'язаними 3 колами вхідного керуючого сигналу, тим КЕР буде більш стійкою до можливих нештатних впливів 3 цих кіл.

Одним із достатньо універсальних рішень $\epsilon$ використання схем, наведених на рис. 4, $a-2$. Усі ці схеми містять резистор R1, який увімкнутий у коло вхідного сигналу, та транзисторний оптрон DA1. Вхідний світлодіод цього оптрона увімкнутий паралельно резистору і живиться від падіння напруги на ньому. Транзистор оптрона увімкнутий за схемою емітерного повторювача і живиться від безперебійного джерела живлення (+5 В DC). Номінал резистора R1 підібраний таким чином, щоб при протіканні заданого струму через нього на виході оптрона DA1 (емітер транзистора) утворилася напруга, яка трохи перевищує половину номінальної напруги безперебійного джерела живлення. Надалі такий сигнал можна подати до входу компаратора, який живиться від тієї самої напруги, що й транзистор оптрона. У підсумку на виході компаратора утвориться дискретний логічний сигнал, що несе інформацію щодо рівня напруги (струму) у вхідному колі. Як компаратор (компаратори) можуть бути використані дискретні входи мікроконтролера, які також апаратно виконують функцію компаратора. Різниця між вхідними сигналами напруги та струму для схем рис. 4, а-б полягає у такому. Для сигналу напруги рис. 4, a номінал R1 має забезпечувати протікання номінального струму через вхідне коло, для сигналу рис. 4, б струм у вхідному колі визначається саме опором послідовно ввімкнутого навантаження, номінал R1 є суттєво меншим за опір навантаження i забезпечує лише спрацювання оптрона за номінального струму.

Для вхідного сигналу змінного струму доцільно застосовувати схему рис. 4, в. Вона відрізняється від схеми рис. $4, a$ використанням оптрона 3 двома ввімкнутими назустріч паралельно вхідними світлодіодами. При застосуванні такої схеми вихідний сигнал з'явиться за вхідного сигналу довільної полярності. Для вхідних сигналів змінного струму $є$ потреба дещо згладжувати вихідний сигнал, для чого використовують конденсатор С1.

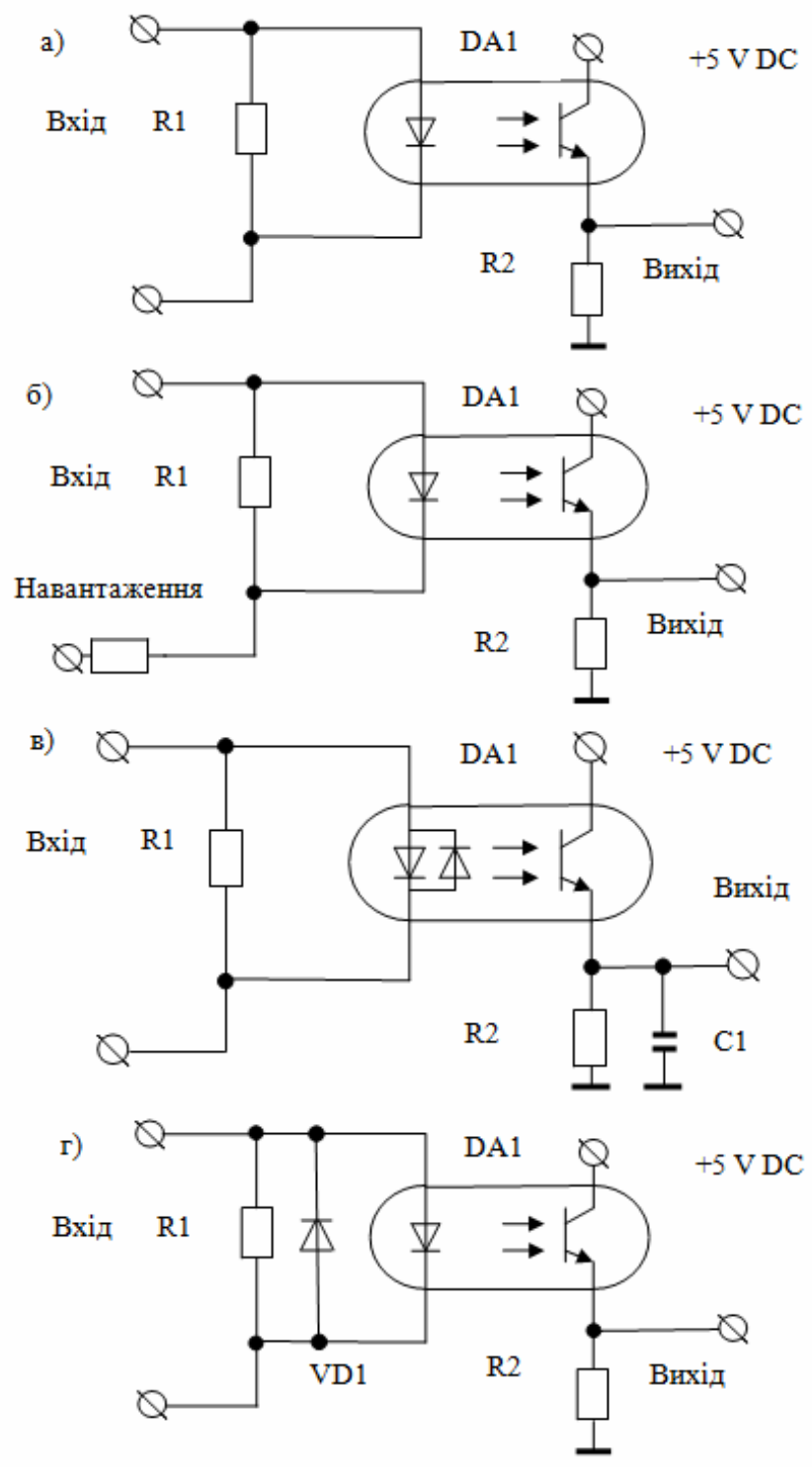

Рис. 4. Схемні рішення:

$a$ - вхідний сигнал напруги постійного струму; $\sigma$ - вхідний сигнал постійного струму;

в - вхідний сигнал напруги змінного струму; 2 - схема, чутлива до полярності вхідного сигналу

Для реагування на сигнали лише позитивної або лише негативної полярності доцільно використати схеми рис. 4, г. У цій схемі сигнал «зайвої» полярності 
проходить не через коло вхідного світлодіода оптрона, а через зовнішній (для оптрона) діод VD1. Завдяки цьому сигнал на виході схеми за умов надходження вхідного сигналу «хибної» полярності буде мати низький (для спрацювання компаратора) рівень.

За наявності вхідного сигналу «необхідної» полярності VD1 опиняється ввімкнутим зворотною полярністю, не впливає на роботу схеми, а сам сигнал призводить до спрацювання оптрона та появи відповідного вихідного сигналу.

Загальна позитивна властивість розглянутих вище схем рис. 4 a-2: при відмові резистора R1 або внутрішнього вхідного світлодіода оптрона довільного типу (обрив чи коротке замикання) схема в цілому не в змозі спрацювати, тобто 3 точки зору понять залізничної функціональної безпеки [6, с. 31] маємо захисну (не небезпечну) відмову. Така сама відмова буде відбуватися при відмові типу «коротке замикання VD1 або R2», обрив у вихідному ланцюгу внутрішнього транзистора оптрона. I тільки два типи відмов - обрив ланцюга R2 або коротке замикання транзистора - $є$ відмовами, які можуть нести (не обов'язково несуть) небезпеку. Яких заходів доцільно вжити для виявлення цих відмов, буде розглянуто нижче.

\section{Приклад реалізації електронного аналога котушки ЕР}

На рис. 5 як приклад застосування схемних рішень, розглянутих вище, наведено схему електронного аналога котушки для ЕР КМШЕ-3000 (електронний аналог ЕМР КМШ-3000). Основними особливостями КМШ-3000 є те, що воно є комбінацією нейтрального (два трійники контактів) та поляризованого (також два трійники контактів) реле [3, с. 351]. Якір нейтральних контактів притягається за напруги не більше за $40 \mathrm{~B}$, відпадає за напруги не менше за 12 В, напруга переключення якоря поляризованих контактів 12-22 В. Залежно від полярності напруги на котушці, що керує якорем поляризованих контактів, цей якір займає одне 3 двох можливих положень - нормальне або переведене. Загальний електричний опір котушок складає 3000 Ом.

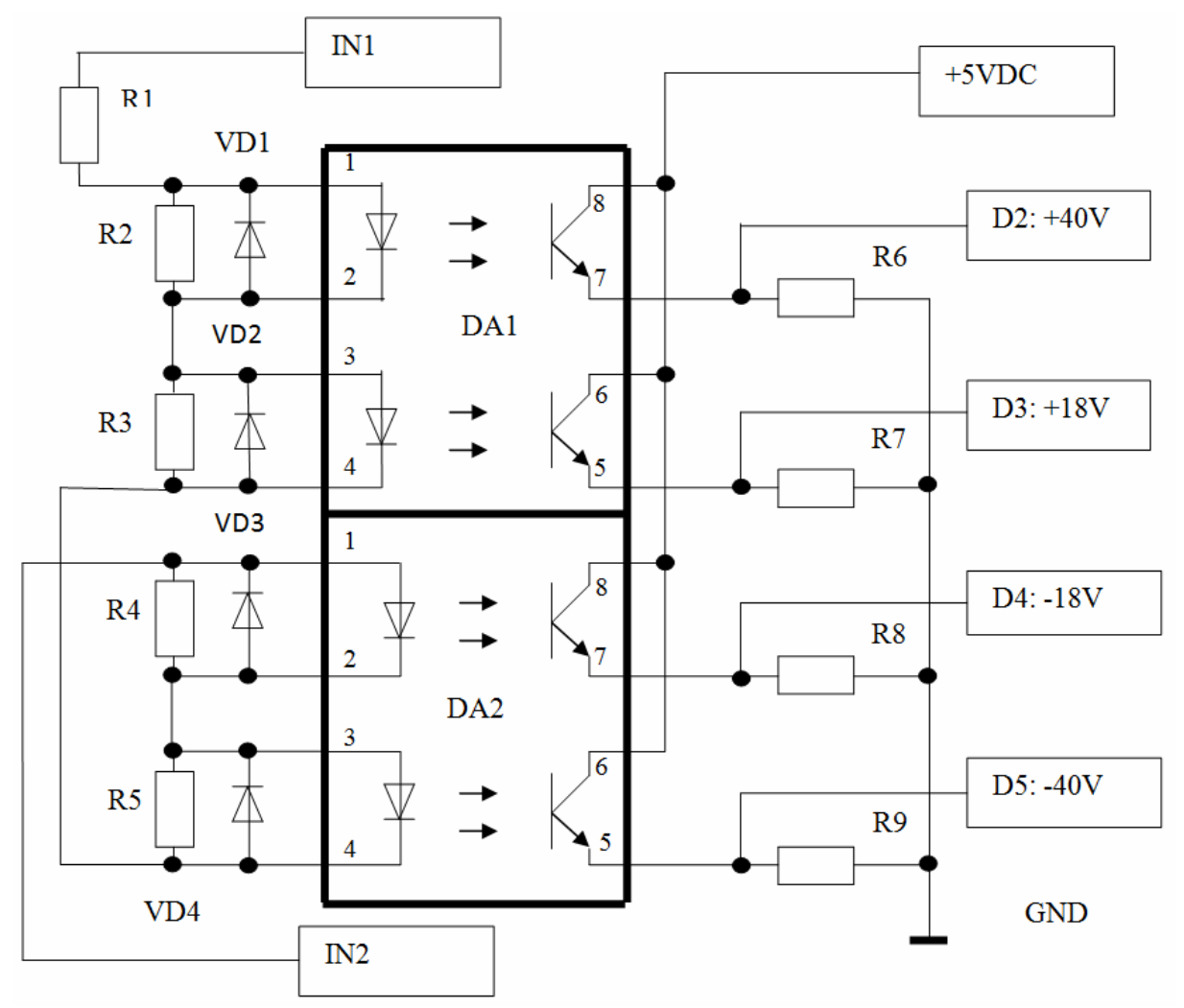

Рис. 5. Електронний аналог котушки КМШ-3000. R1 3,0 K।5W R2, R5 91 Ohm R3.R4 180 Ohm R6-R9 10 K VD1-VD4 1N4148 DA1, DA2 LTV827

Схема, наведена рис. 5, побудована на основі комбінації схемного рішення рис. 4, г. Номінал резистора R1 обраний таким чином, щоб загальний опір вхідного ланцюга розглянутої схеми був тотожним опору ЕMP КМШ-3000. Номінали резисторів R2-R5 обрані такими, щоб забезпечити спрацювання оптронів DA1, DA2 з вихідними сигналами D2-D5 на рівні 2,5 В за наявності вхідної 
напруги IN1-IN2 відповідно: +40 B, +18 B, -18 В, 40 B. Номінал резисторів R6-R9 обмежує струм через транзистори оптронів DA1, DA2 на рівні приблизно 0,5 мA. Діоди VD1-VD4 забезпечують спрацювання відповідних оптронів тільки від сигналу необхідної полярності. Вихідні сигнали D2-D5 надалі надходять до відповідних дискретних входів мікроконтролера (на рис. 5 не показано), де періодично проходять логічну перевірку.

За результатами цієї перевірки цільова програма мікроконтролера може здійснювати відповідні комутування 3 формуванням вихідних дискретних сигналів керування на вольтаїчні оптрони трійників ЕР. Алгоритм комутування є ідентичним логіці роботи
КМШ-3000 i полягає у такому. Спочатку перекидається поляризований якір, потім притягується нейтральний. Спочатку відпадають усі замкнені контакти і потім замикаються всі суміжні у складі трійника розімкнені контакти. Поляризований якір зберігає своє положення після зникнення вхідної керуючої напруги.

Щодо логічної перевірки вихідної інформації схеми рис. 5, то є можливими 16 комбінацій вихідних сигналів D2-D5. Усі вони наведені в табл. 1, але не всі ці комбінації $\epsilon$ коректними. Некоректні комбінації свідчать про відмову певних елементів пристрою. У цих випадках вбудована програма мікроконтролера переводить реле в стан захисної відмови.

Таблиця 1

\begin{tabular}{|c|c|c|c|c|c|}
\hline \multirow{2}{*}{$\begin{array}{c}\text { № } \\
\text { комбінації }\end{array}$} & \multicolumn{4}{|c|}{ Стан виходу } & \multirow{2}{*}{ Коментарі щодо коректності / хибності комбінації } \\
\hline & 2 & 3 & 4 & 5 & \\
\hline 1 & 0 & 0 & 0 & 0 & Коректна. Відсутність вхідного сигналу \\
\hline 2 & 0 & 0 & 0 & 1 & Хибна. Є -40 В і відсутні -18 В \\
\hline 3 & 0 & 0 & 1 & 0 & Коректна. С -18 В \\
\hline 4 & 0 & 0 & 1 & 1 & Коректна. $€-18$ В та -40 В \\
\hline 5 & 0 & 1 & 0 & 0 & Коректна. С +18 В \\
\hline 6 & 0 & 1 & 0 & 1 & Хибна. Присутні + та - одночасно \\
\hline 7 & 0 & 1 & 1 & 0 & Хибна. Присутні + та - одночасно \\
\hline 8 & 0 & 1 & 1 & 1 & Хибна. Присутні + та - одночасно \\
\hline 9 & 1 & 0 & 0 & 0 & Хибна. Є +40 В і відсутні +18 В \\
\hline 10 & 1 & 0 & 0 & 1 & Хибна. Присутні + та - одночасно \\
\hline 11 & 1 & 0 & 1 & 0 & Хибна. Присутні + та - одночасно \\
\hline 12 & 1 & 0 & 1 & 1 & Хибна. Присутні + та - одночасно \\
\hline 13 & 1 & 1 & 0 & 0 & Коректна. Є +18 В та +40 В \\
\hline 14 & 1 & 1 & 0 & 1 & Хибна. Присутні + та - одночасно \\
\hline 15 & 1 & 1 & 1 & 0 & Хибна. Присутні + та - одночасно \\
\hline 16 & 1 & 1 & 1 & 1 & Хибна. Присутні + та - одночасно \\
\hline
\end{tabular}

Як можна зазначити з підсумків аналізу інформації табл. 1, з 16 можливих комбінацій коректними є тільки 5, інші $11 є$ хибними. На підставі цієї інформації можна виявити переважну кількість відмов елементів котушки ЕР та запобігти прояву можливої небезпечної відмови пристрою в цілому.

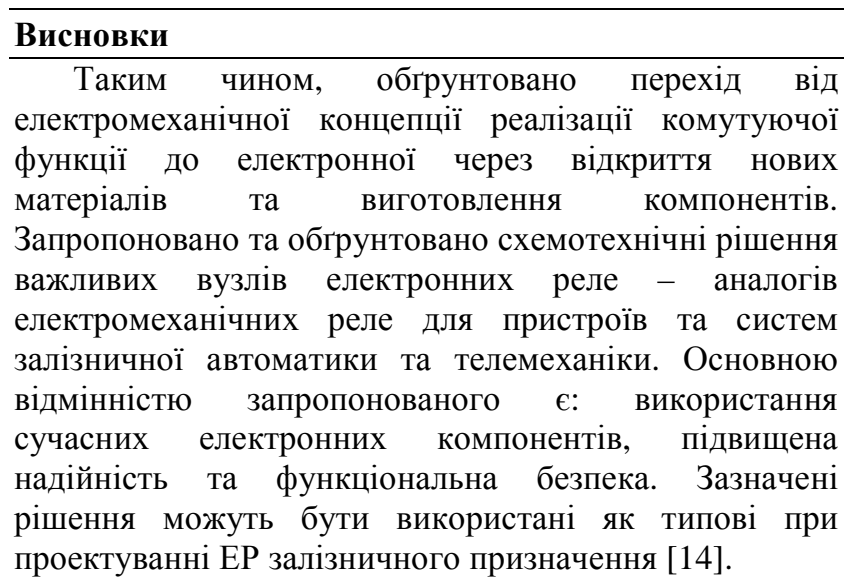

\section{Список використаних джерел}

1. Математичне моделювання в розподілених інформаційно-керуючих системах залізничного транспорту: монографія / С. В. Лістровий, С. В. Панченко, В. І. Мойсеєнко, В. М. Бутенко. Харків: ФОП Бровін О. В., 2017. 220 с.

2. Development of method of definition maximum clique in a non-oriented graph / S. V. Listrovoy, V. M. Butenko, V. O. Bryksin, O. V. Golovko. EasternEuropean Journal of Enterprise Technologies. 2017. Vol. 5, № 4 (89). P. 12-17. DOI: 10.15587/1729-4061.2017.111056

3. Сороко В. И., Фотькина Ж. В. Аппаратура железнодорожной автоматики и телемеханики: справочник в 4 кн. Москва: ООО «НПФ «ПЛАНЕТА», 2013. 1068 c.

4. ДСТУ 4178-2003. Комплекси технічних засобів систем керування та регулювання руху поїздів. Функційна безпечність і надійність. Вимоги та методи випробування. Каталог нормативних документів. Київ: Держспоживстандарт України, 
2003 DSTU 4178-2003. 73 c.

5. ДСТУ 4151-2003. Комплекси технічних засобів систем управління та регулювання руху поїздів. Електромагнітна сумісність. Вимоги та методи випробувань. Каталог нормативних документів. Київ: Держспоживстандарт України, 2003. 15 с.

6. Мойсеєнко В. І., Бутенко В. М., Головко О. В., Чуб С. Г. Проблеми випробувань комплексів технічних засобів керування та регулювання руху поїздів. Інформаційно-керуючі системи на залізничному mранспорті. 2020. № 3(141). C. 31-38. ISSN: 24133833.

7. Воропай А. В. Моделирование нестационарного деформирования прямоугольной пластины с гасителем колебаний. Вестник ХНАДУ. 2011. Вып. 53. С. 87-89.

8. Филипченко И. П., Рыбин Г. Я. Электромагнитные реле. Москва: Советское радио, 1968. 72 с.

9. Миловзоров В. П. Электромагнитные устройства автоматики. Москва: Высшая школа, 1983. 400 с.

10. https://uk.wikipedia.org/wiki/\%D0\%9F\%D0\%B5\%D1 $\% 80 \% \mathrm{D} 0 \% \mathrm{~B} 5 \% \mathrm{D} 1 \% 82 \% \mathrm{D} 0 \% \mathrm{~B} 2 \% \mathrm{D} 0 \% \mathrm{BE} \% \mathrm{D} 1 \% 80$ $\% \mathrm{D} 0 \% \mathrm{~B} 5 \% \mathrm{D} 0 \% \mathrm{BD} \% \mathrm{D} 0 \% \mathrm{BD} \% \mathrm{D} 1 \% 8 \mathrm{~F} \% \mathrm{D} 0 \% 9 \mathrm{~B}$ $\% \mathrm{D} 0 \% \mathrm{~B} 0 \% \mathrm{D} 0 \% \mathrm{BF} \% \mathrm{D} 0 \% \mathrm{BB} \% \mathrm{D} 0 \% \mathrm{~B} 0 \% \mathrm{D} 1 \% 81 \% \mathrm{D}$ $0 \% \mathrm{~B} 0$

11. Channel And Gate Engineered Double Gate MOSFET. LAP Lambert Academic Publishing, 2014.

12. IRFP22N60KPBF pdf, IRFP22N60KPBF description, IRFP22N60KPBF datasheets, IRFP22N60KPBF view $\because:$ ALLDATASHEET $::$ :

13. 1.5KE440CA. Data Sheet.

[https://datasheetspdf.com/pdf/775851/

Littelfuse/1.5KE440CA/1].

14. GOST 2.749-84. Unified system of design documentation. Graphic identifications schemes Elements and means of railway sig naling, centralization and blocking // CT SEV 5680-86. M.: Standarts, 2001. 28 p.

Butenko V. M., Golovko O. V., Sergiienko R. P., Chub S. G. Improvement of principal schemes of information-measuring and switching components of railway automation systems.

Abstract. Technical re-equipment of the national railway, incl. the introduction of new means and systems of railway automation is one of the important directions of the development of the railway branch management systems. Existing systems of national railway automation are built using various electromechanical relays. These relays have been developed a long time ago and not all of them are manufactured in Ukraine.

Recently, electronic relays (ER) that can reproduce the functions of electromagnetic relays similar in purpose, have become widespread among the means of railway automation. However, the final product of the ER differs significantly from the electromagnetic in its structure, maintainability, and other important characteristics. At the same time, the world's leading developers of electronic (solid-state) relays have some experience and typical industrial solutions that have proven themselves in various areas. There is a significant difference between generalpurpose relays and ERs for railway automation. The last ones, in particular, have high requirements for the level of reliability and functional safety. Thus, it is quite important to develop circuit solutions ER, which would cover the positive experience of developers and contain advanced solutions of world leaders.

The paper develops and substantiates circuit solutions of important components of the ER, which could later become typical for use in components, subsystems, and systems of railway automation as components of specialized computer systems for the routes safety technological calculations.

ERs have certain advantages over electromechanical analogs. First of all, it is a high-reliability connection. The norm for electromechanical relays of the first (highest) class of reliability is one million guaranteed operations on contacts without electric load. Ordinary electronic contacts easily overlap this norm by several orders of magnitude.

However, electronic contacts have their own characteristics. To date, for the ER circuits most widely used MOSFET-transistors with the induced channels as electronic contacts.

The article presents a typical circuit of an electronic switch of alternating current signals, a scheme of the corresponding tee of electronic contacts, as well as certain circuit solutions of electronic analogs of the relay coil.

The main difference of the proposed is the use of modern electronic components, increased reliability, and functional safety.

Keywords: electronic relay, contact, switch, optocoupler, MOSFET-transistor.

Надійшла 10.10.2021 p.

Бутенко Володимир Михайлович, кандидат технічних наук, доцент кафедри спеціалізованих комп'ютерних систем, Украӥнський державний університет залізничного транспорту, Харків, Україна. E-mail: butenko@kart.edu.ua http://orcid.org/0000-0001-9958-3960

Головко Олександра Володимирівна, кандидат технічних наук, доцент кафедри обчислювальної техніки та систем управління, Украӥнський державний університет залізничного транспорту, Харків, Україна. E-mail: golovko@kart.edu.ua. http:// orcid.org/0000-0002-9880-428X

Сергієнко Римма Петрівна, кандидат технічних наук, інженер ДП «Харківстандартметрологія», м. Харків, Україна. E-mail: $\quad$ rimmasergienko474@gmail.com http://orcid.org/0000-0003-4800-1013. 
Чуб Сергій Григорович, кандидат технічних наук, дочент, провіднй інженер ДП «Харківстандартметрологія», м. Харків, Україна. Еmail: chub.3.6.49@gmail.com http://orcid.org/0000-0002$\underline{4375-4676}$

Butenko Volodymyr M., PhD, Associate Professor department of specialized computer systems, Ukrainian State University of Railway Transport, Kharkiv, Ukraine. E-mail: butenko@kart.edu.ua http:// orcid.org/00000001-9958-3960

Golovko Oleksandra V., PhD, Associate Professor department of Computer Engineering and Control Systems, Ukrainian State University of Railway Transport, Kharkiv, Ukraine. E-mail: golovko@kart.edu.ua http:// orcid.org/0000-0002-9880-428X

Sergiienko Rymma P., PhD, Associate Professor, SE "Kharkivstandartmetrologiia", Kharkiv. E-mail: rimmasergienko474@gmail.com http://orcid.org/00000003-4800-1013

Chub Sergii G., PhD, Associate Professor, SE "Kharkivstandartmetrologiia", Kharkiv. E-mail: chub.3.6.49@gmail.com http://orcid.org/0000-0002$\underline{4375-4676}$ 